\title{
Expression of Extracellular Matrix \\ Proteins in Human Periodontal \\ Ligament Cells During \\ Mineralization In Vitro
}

\author{
Rahime M. Nohutcu, ${ }^{*}$ Laurie K. McCauley, ${ }^{*}$ Amy J. Koh, ${ }^{*}$ and \\ Martha J. Somerman*ः
}

PERIODONTAL REGENERATION IS A COMPLEX PROCESS that requires coordinated responses from several cell types within the periodontium. It is generally accepted that the periodontal ligament (PDL) has a heterogeneous cell population, where some of the cells may be capable of differentiating into either cementoblasts or osteoblasts. Thus, it has been hypothesized that PDL cells play a role in promoting periodontal regeneration. However, definitive evidence to support this concept is lacking. Previously, we reported that PDL cells induce biomineralization as determined by Von Kossa histochemistry and transmission electron microscopy. To further determine the osteoblast-like properties of PDL cells, human PDL cells were exposed to dexamethasone (DEX) in order to promote an osteoblast phenotype, and then cell activity monitored during mineral nodule formation in vitro. For mineralization studies, cells were cultured in DMEM containing $10 \%$ FBS and a) vehicle only; b) ascorbic acid $(50 \mu \mathrm{g} / \mathrm{ml})$ and $\beta$-glycerophosphate $(10$ $\mathrm{mM})$; or c) ascorbic acid, $\beta$-glycerophosphate and DEX $(100 \mathrm{nM})$ for 30 days. In addition, the effects of DEX on PDL cells in non-mineralizing media were determined. Cells were stained weekly to evaluate mineral-like nodules, using the Von Kossa method. Northern blot analyses for mRNA steady state levels for several bone-associated proteins, i.e., osteopontin (OPN), bone sialoprotein (BSP), alkaline phosphatase (ALP), osteocalcin $(\mathrm{OCN}), \alpha_{2}(1)$ (type 1) collagen and osteonectin $(\mathrm{ON})$, were performed. DNA levels were also determined during the 30-day mineralization period. Under phase contrast microscopy, PDL cells in non-mineralizing media treated with DEX exhibited a more spindle-shaped morphology when compared with similar cells not exposed to DEX. Mineralizing conditions were required to induce mineral nodule formation. However, in this situation, mineral induction was independent of DEX; and furthermore, DEX-treated cells did not exhibit a different morphological pattern when compared with non-DEX treated cells. Mineral-like nodules were first seen at day 15, in concert with an increase followed by a decrease in expression of type I collagen and ON mRNA in both DEX-treated and non-treated cultures. Using Northern blot analysis for detection of specific proteins, we found that PDL cells did not express OPN, BSP, OCN, or ALP under any of the conditions used in this study. DEX did not alter DNA content in the cultures during the mineralization period. These results confirm that human periodontal ligament cells can be induced to mineralize in vitro and indicate that dexamethasone does not significantly alter the extent and pattern of mineralization. $J$ Periodontol 1997; $68: 320-327$.

Key Words: Cells, cultured; periodontal ligament/physiology; mineralization.

\footnotetext{
*Department of Periodontics/Prevention/Geriatrics, University of Michigan, Ann Arbor, MI.

'University of Hacettepe, Faculty of Dentistry, Department of Periodontology, Ankara, Turkey.

Department of Pharmacology, University of Michigan.
}

Ideal healing after regenerative periodontal procedures entails development of a new connective tissue attachment with the formation of new cementum, new bone, and functionally oriented collagen fibers ${ }^{1-3}$ (PDL). While 
the exact role of specific cell types within the periodontium in the regenerative process is not yet established, ${ }^{4}$ current evidence supports the concept that periodontal regeneration is promoted through the activation of cells in the remaining healthy portion of the periodontal ligament, as well as through activation of cells in the perivascular region. ${ }^{4-6}$ Studies focusing on the characterization of PDL cells in vitro indicate that these cells have osteoblast-like properties including synthesis and expression of alkaline phosphatase (ALP) and osteopontin (OPN), 1,25 dihydroxyvitamin $\mathrm{D}_{3}$-induced bone 'gla' protein synthesis, responsiveness to parathyroid hormone (PTH), and dexamethasone-(DEX) induced PTH-mediated cAMP synthesis. ${ }^{7-14}$ Furthermore, PDL cells have the capacity to produce mineralized nodules in vitro under appropriate conditions, i.e., in mineralization medium which includes ascorbic acid, $\beta$-glycerophosphate and the glucocorticoid, dexamethasone. ${ }^{7,14-18}$ Further, using transmission electron microscopy, we demonstrated that mineralization is associated with collagen fibrils. ${ }^{15}$ These findings led researchers to hypothesize that progenitor cells of cementoblasts and osteoblasts exist in PDL tissue, and that PDL cells, at least in part, are responsible for stimulating and directing regeneration of the periodontium in vivo. ${ }^{1-6}$ However, definitive evidence demonstrating that PDL tissues contain osteoprogenitor cells having the capacity to differentiate into osteoblasts and/or cementoblasts in vivo or in vitro is lacking. ${ }^{6.19}$ Our recent studies demonstrated that PDL cells in vitro, when exposed to dexamethasone (DEX), elicited a dose-dependent increase in cAMP production in response to PTH stimulation. ${ }^{11}$ This prompted us to further characterize the properties of DEX-treated PDL cells in vitro. DEX has been shown to selectively stimulate osteoprogenitor cell proliferation and to induce osteoblastic cell differentiation in many other cell systems. ${ }^{20-24}$ The fact that mineralization medium, which contains ascorbic acid, $\beta$-glycerophosphate and DEX, induces mineralization in PDL cultures suggests that factors such as DEX may influence differentiation. In the presence of DEX, rat marrow stromal cells have been reported to promote mineralized nodules. ${ }^{24-26}$ Furthermore, removal of DEX from mineralization media prevented bone marrow stromal cell-induced nodule formation. Although several reports imply the permissive role of dexamethasone in initiating differentiation of osteoprogenitor cells, the precise role of this agent in modulating metabolism and biologic activity of human osteoblastic and fibroblastic cell systems is not known.

In the present study, the ability of DEX to influence PDL cell-induced mineralization in vitro was determined. Furthermore, mRNA expression of specific genes representative of the osteoblastic phenotype, including alkaline phosphatase (ALP), osteocalcin (OCN), and bone sialoprotein (BSP) was determined during differentiation in vitro.

\section{MATERIALS AND METHODS}

\section{Supplies}

Cell culture media and supplements were purchased, $\$$ along with dexamethasone, calf thymus DNA, $\beta$-glycerophosphate," ascorbic acid, " nylon membranes and random primer labeling kit," and ${ }^{32}$ P-dCTP.**

\section{Cell Isolation and Culture}

PDL fibroblasts were isolated and cultured as reported in detail previously. ${ }^{9}$ Briefly, PDL tissues were obtained from the periodontal ligaments of premolar teeth extracted for orthodontic reasons. After extraction the teeth were placed in biopsy media (Dulbecco's modified Eagles media [DMEM] with $10 \%$ fetal bovine serum [FBS], 250 $\mu \mathrm{g} / \mathrm{ml}$ gentamicin sulfate, $5 \mu \mathrm{g} / \mathrm{ml}$ amphotericin $\mathrm{B}, 100$ units $/ \mathrm{ml}$ penicillin, $100 \mu \mathrm{g} / \mathrm{ml}$ streptomycin). Only periodontal ligament attached to the middle third of the root was removed with a scaler to avoid contamination with gingival and apical tissues. The PDL tissues were cut into small pieces, rinsed with biopsy media, placed in tissue culture dishes, and glass cover slips were placed over the tissues to prevent floating. PDL tissues were incubated in biopsy medium in a humidified atmosphere of $95 \%$ air and $5 \% \mathrm{CO}_{2}$ at $37^{\circ} \mathrm{C}$ overnight. The following day, biopsy medium was replaced with culture medium (DMEM with $10 \%$ FBS, 100 units/ml penicillin, $100 \mu \mathrm{g} / \mathrm{ml}$ streptomycin). After reaching confluence, cells were passaged with $0.25 \%$ trypsin- $0.1 \%$ ethylene diaminotetraacetic acid (EDTA). PDL cells were used between the 4th and 6th passage for all experiments.

\section{Mineralization Protocol}

Previously, we found that human PDL cells, cultured as described in the present study, induce formation of mineral nodules that are associated with collagen fibrils, i.e., biomineralization as determined by electron microscopy and Von Kossa analysis. ${ }^{15}$ For the studies here, to correlate gene expression with mineralization, Von Kossa histochemistry was used. PDL cells were seeded at an initial density of 30,000 cells $/ \mathrm{cm}^{2}$ in $35 \mathrm{~mm}$ dishes. Before reaching confluence, culture dishes were divided into 3 groups and cells were cultured in DMEM containing a) 10\% FBS (control); b) 10\% FBS with mineralization supplements $(50 \mu \mathrm{g} / \mathrm{ml}$ ascorbic acid, $10 \mathrm{mM} \beta$-glycerophosphate); or c) $10 \%$ FBS, mineralization supplements and dexamethasone $(100 \mathrm{nM})$ for 30 days. The media for all groups were changed every 2 days. To detect formation of mineral-like nodules, the cells were fixed and

\footnotetext{
Gibco BRL, Grand Island, NY.

ISigma Chemical Co., St. Louis, MO.

TAldrich Chemicals, Milwaukee, WI.

"Stratagene, La Jolla, CA.

**NEN Dupont, Boston, MA.
} 
stained weekly, using the Von Kossa method as described. ${ }^{27}$ Briefly, cells were fixed with $95 \%$ ethanol and flooded with $5 \% \mathrm{AgNO}_{3}$ for 1 hour, washed with distilled water, then exposed to light for 30 minutes.

\section{Northern Blot Analyses}

PDL cells were plated at a density of 30,000 cells $/ \mathrm{cm}^{2}$ in $60 \mathrm{~mm}$ tissue culture dishes and treated with DMEM containing mineralization supplements and vehicle or dexamethasone $(100 \mathrm{nM})$ for 30 days. Media were changed every 2 days and at days $0,3,7,10,15,20,25$, and 30 ; total RNA from each group was isolated by the guanidinium isothiocyanate method ${ }^{28}$ and quantified by $\mathrm{A}_{260}$. Total RNA $(20 \mu \mathrm{g})$ was denatured and electrophoresed in sample buffer (50\% formamide, $10 \%$ 3-(N-morpholino) propane sulfonic acid (MOPS) buffer, $18 \%$ formaldehyde, $10 \%$ glycerol, $0.5 \%$ bromophenol blue, $1 \mu \mathrm{g}$ ethidium bromide) on $1.2 \%$ agarose formaldehyde gels. RNA was transferred to nylon membranes via passive transfer and crosslinked by ultraviolet transillumination. The following cDNA probes were used: mouse collagen type I $\left(\alpha_{2}\right.$ I), ${ }^{29}$ rat parathyroid hormone/parathyroid hormone-related protein (PTH/PTHrP) receptor (R15B), ${ }^{30}$ mouse alkaline phosphatase $^{31}$ (ALP), human osteopontin (OPN), ${ }^{32}$ rat bone sialoprotein (BSP), ${ }^{33}$ rat osteonectin (ON), ${ }^{34}$ rat osteocalcin $(\mathrm{OCN})^{35}$ and 18S rRNA ${ }^{36}$ (control for loading). All cDNA probes were labeled with ${ }^{32} \mathrm{P}$-deoxycytidine triphosphate (dCTP) using random primer labeling. The nylon membranes were pre-hybridized for 1 hour at $42^{\circ} \mathrm{C}$ ( $53 \%$ formamide, $0.2 \%$ sodium dodecyl sulfate [SDS], and $1 \mathrm{mg} / \mathrm{ml}$ denatured salmon sperm DNA) followed by the addition of labeled cDNA probes and hybridized overnight at $42^{\circ} \mathrm{C}$. The membranes were washed 8 times for 15 minutes each, increasing the temperature to $50^{\circ} \mathrm{C}$ with decreasing concentrations of salt sodium citrate (SSC) in $0.1 \%$ SDS. The blots were exposed to Kodak X-OMAT film with intensifying screens for various times at $-70^{\circ} \mathrm{C}$ and developed in an automatic film processor.

The relative expression of mRNA on autoradiographs was determined by scanning densitometry using NIH Image and a computer. ${ }^{+\dagger}$ The data are expressed as a ratio of mRNA signal to $18 \mathrm{~S}$ rRNA signal and standardized to 1.0 at day 0 .

\section{DNA Measurement}

The DNA content was determined in cell lysates prepared for RNA isolation. DNA was measured using the fluorochrome bisbenzimidazole (Hoescht 33258) with a fluorometer ${ }^{\sharp \neq}$ according to a method modified from that of Rymaszewski et al. ${ }^{37}$ Briefly, DNA standards or cell lysates were mixed with $2 \mathrm{ml}$ assay buffer (1 mM EDTA,

\footnotetext{
${ }^{\dagger+}$ Power Mac 8100, Apple Computers, Cupertino, CA.

¥¥TKO 100-Mini Fluorometer, Hoefer Scientific Instruments, San Francisco, CA.
}

$10 \mathrm{mM}$ tris base, $200 \mathrm{mM}$ sodium chloride [pH 7.4] and $0.2 \mu \mathrm{g} / \mathrm{ml}$ fluorochrome bisbenzimidazole). The DNA content of calf thymus standard was calibrated and each sample-was read in duplicate. The DNA content in cell lysates was quantified using a regression line as the standard curve, and results were expressed as the mean \pm standard error of the mean (SEM) of duplicate samples.

\section{Statistical Analyses}

Data for the DNA levels in cultures were evaluated using a statistical software program. $\$$ Analysis of variance followed by multiple comparisons using Tukey's mean separation test was used to determine statistical significance.

\section{RESULTS}

\section{Morphology}

Nodules were first detected visually in PDL cultures induced to mineralize between days 15 and 20 , and increased in size and number thereafter. The Von Kossa staining method was used to localize phosphate deposits in PDL cultures weekly (day 20; Fig. 1). PDL cells, cultured with mineralization supplements, displayed nodule formation that was qualitatively similar in size and extent with or without DEX supplementation (Fig. 1B, C). There were no Von Kossa-positive nodules in the PDL cultures without mineralization supplements (Fig. 1A). These findings were reproduced in four separate experiments.

Although there was no difference in mineralized nodule appearance with DEX, there were striking differences in PDL cell morphology with DEX treatment in the cultures that were not supplemented with ascorbic acid and $\beta$-glycerophosphate. The DEX-treated cells appeared to be more densely packed and had a spindloid morphology compared to the more cuboidal yet elongated control PDL cells (Fig. 2).

\section{Northern Blot Analyses}

Northern blot analyses revealed a similar pattern of steady state collagen type I gene expression in cultures with mineralization supplementation with or without DEX treatment. In both groups, collagen type I mRNA levels increased 2 -fold to peak values at day 10 , and subsequently decreased. The peak of collagen expression preceded the appearance of the first mineral-like nodules observed by Von Kossa staining (Fig. 3). Osteonectin (ON) mRNA levels were higher initially (days $0,3,7$, and 10) and subsequently declined prior to the time when mineral-like nodules were first detected (Fig. 4). The pattern of ON mRNA expression was similar with or without DEX treatment.

There were no detectable mRNA signals on autoradiographs for PTH/PTHrP receptor, ALP, OPN, BSP, or

\$Instat 2.1, Graph-PAD Software, San Diego, CA. 

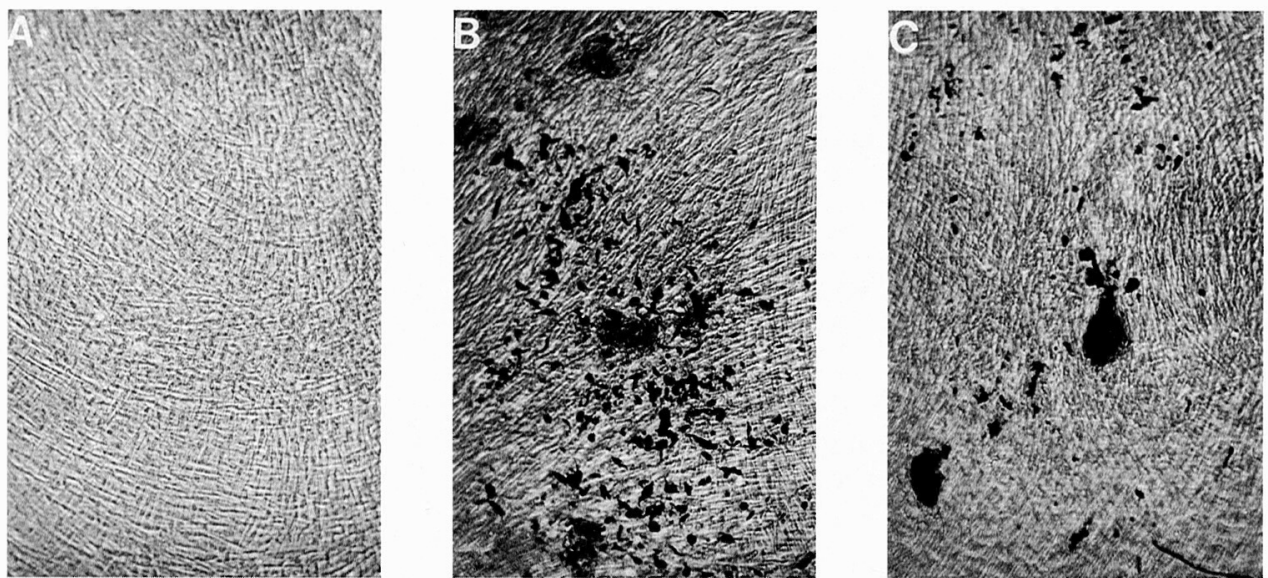

Figure 1. Phase contrast micrographs of PDL cells after 20 days of culture and staining for mineralized nodules using the Von Kossa method. A) control, no mineralization supplements; $\boldsymbol{B})$ mineralization supplements (50 $\mathrm{\mu g} / \mathrm{ml}$ ascorbic acid, $10 \mathrm{mM} \beta$-glycerophosphate); and C) mineralization supplements plus DEX $(100 \mathrm{nM})$. Mineralized nodules were detected to a similar extent in cultures with mineralization supplements with or without DEX, whereas no nodules were detected in the control group.
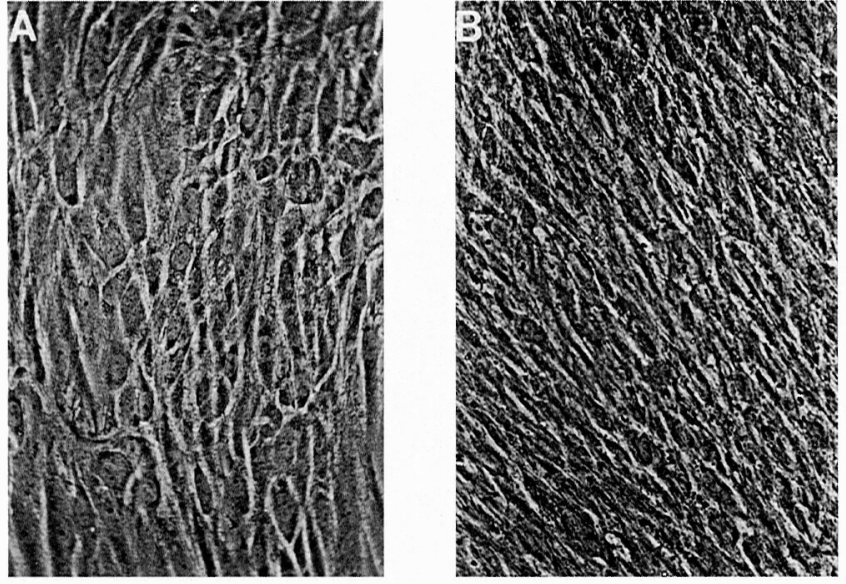

Figure 2. Phase contrast micrographs of PDL cell cultures treated with A) control (vehicle only) or B) DEX (100 nM). DEX-treated cells appeared to be more densely packed and had a more spindloid morphology.

OCN, although positive signals were detected with appropriate osteoblast controls (data not shown).

\section{DNA Content}

DNA levels increased rapidly between days 3 and 7 and reached a plateau thereafter. The total DNA content in cell lysates was similar with or without DEX treatment (Fig. 5).

\section{DISCUSSION}

The results of this study confirm that periodontal ligament cells can initiate mineral-like nodules in vitro, as demonstrated previously by several groups. ${ }^{7.15,17}$ During the first 10 to 12 days after plating cells, DNA levels of the cultures showed a marked increase followed by a plateau. This is in agreement with the data of Stein et al. ${ }^{38}$ who reported an increased expression of $\mathrm{H} 4$, a reflection DNA synthesis, in fetal calvaria-derived cells during differentiation. Although morphological differences were noted in DEX-treated, non-mineralization media cultures versus control cultures (i.e., non-mineralization media), dexamethasone treatment did not alter the capacity of PDL cells exposed to mineralization media to form minerallike nodules. Furthermore, similar expression patterns of type I collagen and osteonectin (ON) mRNA expression were observed in DEX-treated and DEX(-) cultures during mineralization in vitro. We had predicted that cells exposed to DEX would behave significantly different from unexposed cells in vitro. Several reports using bone culture systems reported that DEX stimulated proliferation of osteoprogenitor cells and/or enhancement of bone matrix gene expression. ${ }^{20-24}$ The lack of such responsiveness of PDL cells in vitro to DEX in the studies described presents an intriguing finding likely due to multiple factors.

Previous studies have shown that, following a proliferative phase, bone cells differentiate and begin to deposit a collagenous matrix that subsequently supports maturation of the osteoblast phenotype ${ }^{39-41}$ In the present study, type I collagen gene expression increased until the time that mineral-like nodules were first detected, and declined thereafter. This is similar to findings reported for the in vitro differentiation of primary osteoblastic cells. ${ }^{39,40}$ Franceschi and Iyer, using a pre-osteoblastic cell line, MC3T3-E1 cells, have shown that collagen synthesis and/ or accumulation is required for subsequent expression of ascorbic acid-dependent promotion. ${ }^{41}$ Kasugai et al. reported a 5-fold increase of the production of type I and type III collagens in dental pulp cells after DEX supplementation of mineralization-inducing media, as well as a greater number of mineralized nodules when compared to cultures without dexamethasone. ${ }^{42}$ In our study, we did 


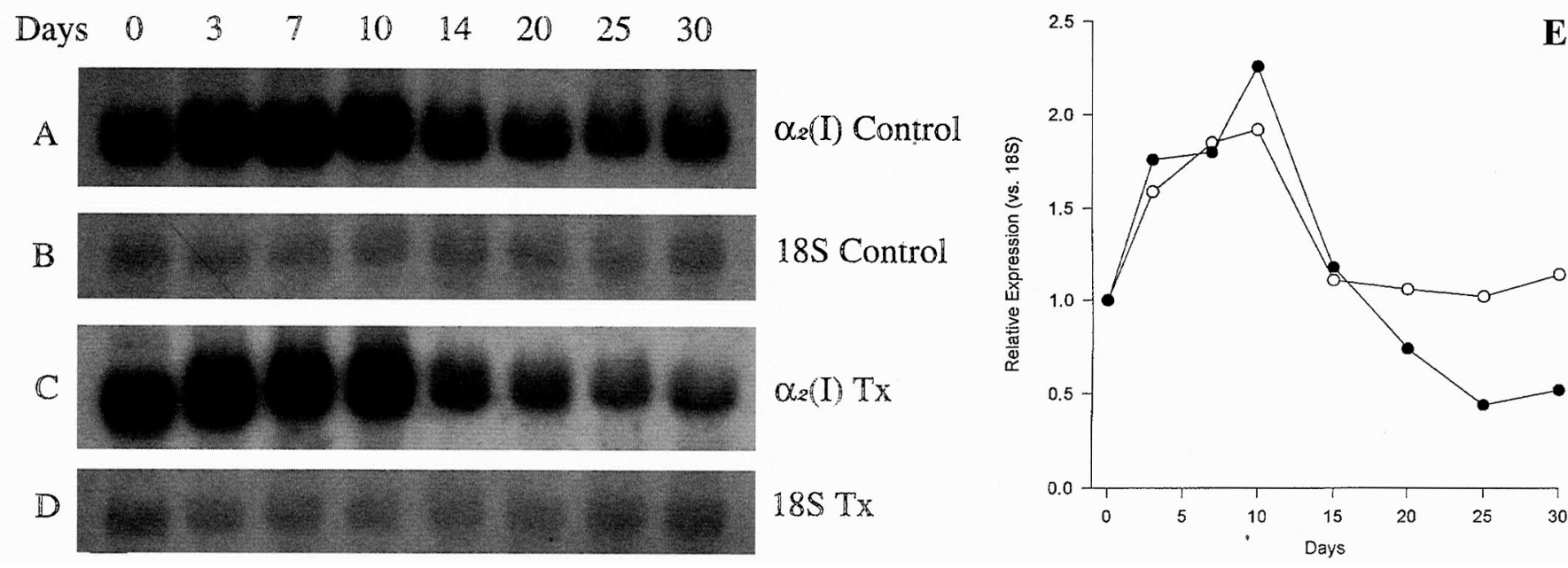

Figure 3. Northern blot analysis for $\alpha_{2}(I)$ (type I) collagen mRNA expression during 30-day mineralization protocol. A) autoradiograph of $\alpha_{2}(I)$ collagen $m R N A$ expression for control cultures; $\boldsymbol{B}$ ) autoradiograph of $18 S$ rRNA for control cultures; $C$ ) autoradiograph of $\alpha_{2}(I)$ collagen for DEXtreated (100 nM) cultures; D) $18 S$ rRNA for DEX-treated cultures; and $\boldsymbol{E}$ ) plot of scanning densitometry values representing ratio of relative expression of $\alpha_{2}(I)$ collagen to $18 S$ rRNA for autoradiographs in $A-D$ (control $=0 ; D E X=0$ ).
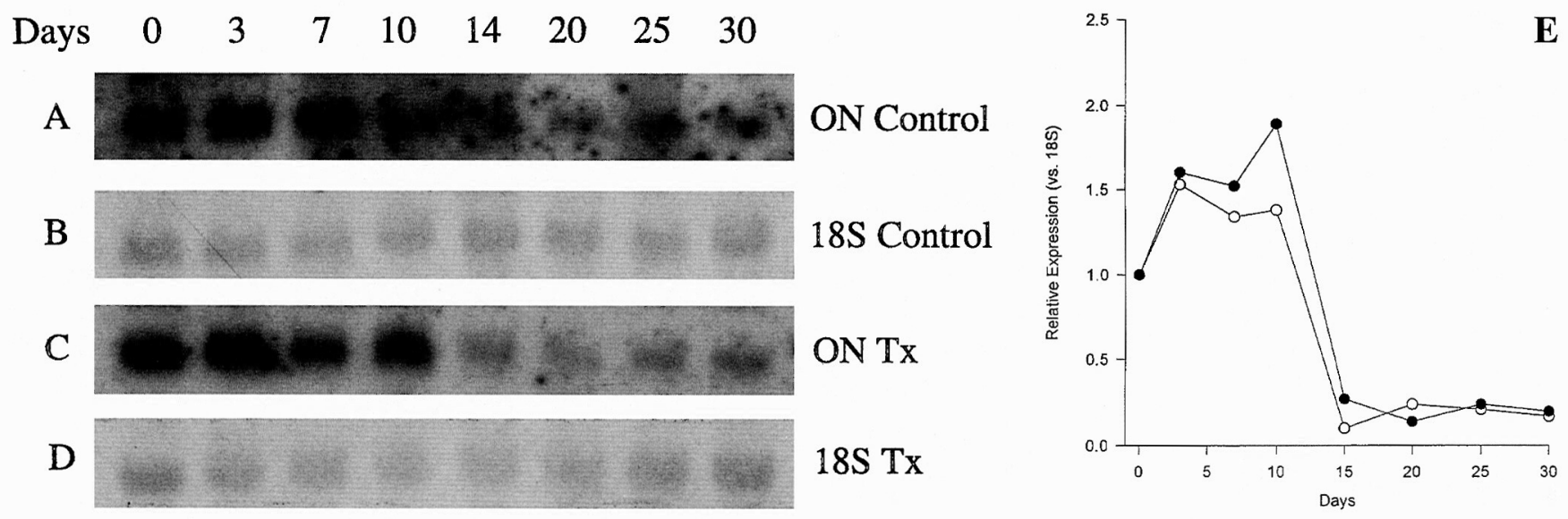

Figure 4. Northern blot analysis for osteonectin mRNA expression during 30-day mineralization protocol. A) autoradiograph of osteonectin mRNA expression for control cultures; B) autoradiograph of $18 S$ rRNA for control cultures; $C$ ) autoradiograph of osteonectin for DEX-treated (100 nM) cultures; $\boldsymbol{D})$ autoradiograph of $18 S$ rRNA for DEX-treated cultures; and $\boldsymbol{E}$ ) scanning densitometry values representing ratio of relative expression of osteonectin to I8S rRNA for autoradiographs in $A-D$ (control $=0 ; D E X=0$ ).

not analyze cells for total protein or type I collagen production. However, it can be inferred from our finding of high levels of type I collagen mRNA expression prior to presence of detectable mineral-like nodules, that increased synthesis and deposition of collagen were required for subsequent events in mineralizing PDL cultures, similar to those seen in other culture systems.

In addition to determining changes in expression of type I collagen in DEX-treated cells, we also determined whether this treatment influenced gene expression of several other proteins associated with mineralization. Although ON/SPARC is not considered to be involved in bone formation and mineralization, it is believed to play a role in extracellular matrix proteolysis. It has also been called a culture shock protein since it is found in high levels in many cultured cells. ${ }^{43}$ Since ON's expression during development has been found to be steady, rather than specific for osteoblastic differentiation, it is considered to be a product characterized as an essential element for connective tissue development. ${ }^{44}$ In the present study, ON steady state mRNA levels were similar in the mineralization cultures treated with or without dexamethasone. Interestingly, high levels of ON mRNA were noted at early time points, as often seen when cells are placed in culture, but declined with onset of mineralization. Takano-Yamamoto et $\mathrm{al} .{ }^{45}$ suggested that $\mathrm{ON}$ may play a role in regulating the mineralization process within the PDL, based on their findings of high levels of ON mRNA within the PDL of erupted teeth, as determined by in situ hybridization. Thus, while speculative at this point, it is possible that decreased expression of $\mathrm{ON}$ during mineralnodule formation in vitro assists in the formation of nod- 


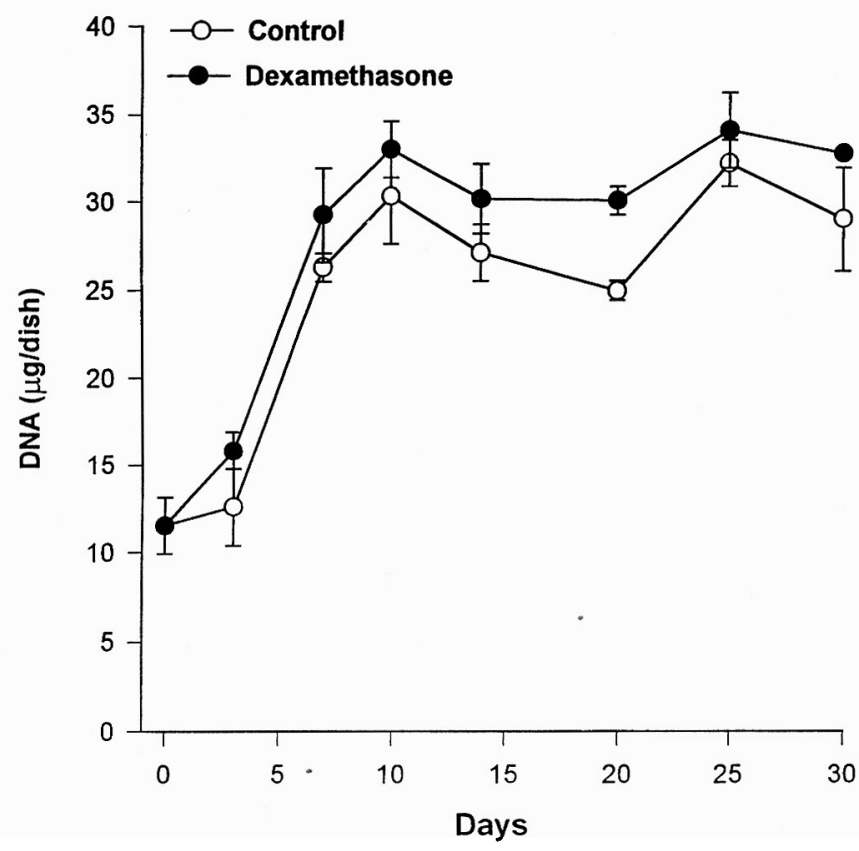

Figure 5. Mean DNA levels ( \pm SEM) for PDL cell cultures with mineralization supplements over 30-day culture period.

ules. However, results from other studies directed at determining expression of specific proteins during mineralization are not consistent with our findings. Results from other studies report: 1) an increase in ON expression, measured at only one time point, day 14 , using rat bone marrow cells. ${ }^{23}$ In the absence of DEX these cells do not induce mineralization; or 2) no change in constitutively expressed ON mRNA during mineralization using rat bone marrow cultures, ${ }^{24}$ or bovine bone cells. ${ }^{44}$ In the latter situation, DEX was not required for the induction of mineralization. The difference in our findings when compared with others can be attributed to several factors which include differences in cell types and species used, the high number of non-osteoblast-like cells in the PDL cultures, especially with passage, ${ }^{46}$ and the time points studied.

The mRNA signals for other proteins examined were not strong enough for detection by Northern analysis. We had anticipated that cells exposed to DEX plus mineralization media would exhibit mRNA for proteins associated with the osteoblast phenotype. This was based on our studies demonstrating that DEX promoted an increase in PTH-mediated cAMP response by PDL cells in vitro. ${ }^{11}$ Thus, we hypothesized that a small population of cells within the culture had the capacity to function as osteoblasts when stimulated appropriately, i.e., mineralization media plus DEX. The lack of expression of message for proteins reported to be increased in pre-osteoblasts undergoing mineralization in culture can be attributed to several factors. First, only a few cells might be responsible for the mineral-like nodules formed in PDL cultures, and the density of this selective cell population may not be sufficient for detection of specific mRNAs by Northern blot analysis. This possibility is supported by several other studies on PDL cells and on osteoblasts in culture. Nohutcu et al. ${ }^{46}$ demonstrated that freshly isolated PDL cells express OPN and BSP mRNAs at very low levels, and when these cells are cultured for three passages, message for these proteins was not detectable by Northern analysis. Results from other studies provide evidence that osteoblasts, but not PDL cells, promote significant formation of bone/cementum-like material in vivo and in vitro. ${ }^{19,47.48}$ Furthermore, in bone cell systems in culture, only a small number of cells differentiate, thus providing the appropriate environment for organizing their extracellular matrix into a bone-like structure. ${ }^{24.49}$ Second, gene expression for specific proteins may be transient in PDL cells and not detected by our selection time periods. ${ }^{46}$ For example, early expression of alkaline phosphatase may be sufficient to initiate mineralization. Importantly, initiation and progression of mineralization are separate phenomena, and organic phosphate and alkaline phosphatase play a crucial role in initiation of mineralization ${ }^{50,51}$ but are not required for continued nodule formation. ${ }^{52}$ Alternatively, it is possible that a very limited number of cells expressed bone-associated proteins, but could not be detected by Northern analysis. Further studies, using in situ hybridization to analyze for specific proteins during PDL cellinduced mineral nodule formation in vitro, may help to determine if a very small population of cells is expressing proteins classically associated with the mineralization process, in vitro. Third, methods used for isolation of PDL cells for in vitro studies vary considerably. Importantly, Lin et al. and Ramakrishnan et al., using a different isolation method, have found a PDL population expressing classical osteoblast features including alkaline phosphatase. ${ }^{6,18}$ They used an extraction socket wound healing model in rats, in which cells were obtained from the healing socket 2 days following tooth extraction. In contrast, most other groups obtain PDL tissues for culture from functional PDL regions of premolars extracted for orthodontic reasons or from the region of third molars. ${ }^{7-13,15,17.47,48}$

The results from this study indicate that DEX does not significantly alter the extent and pattern of PDL cell mineralization in vitro. Future studies directed at cloning selected populations of cells within the PDL will enhance our understanding about the role of these cells during maintenance, disease, and regeneration/repair of periodontal tissues.

\section{Acknowledgments}

Manuscript preparation by Mary L. Schmidt is appreciated. Investigations were supported in part by NIH grants DK46919 and DE09532; Procter and Gamble, Miami Val- 
ley; and ECZACIBASI Procter and Gamble Oral Care Scientific Research and Award Fund, Turkey.

\section{REFERENCES}

1. Nyman $S$, Lindhe J, Karring T, Rylander $H$. New attachment following surgical treatment of human periodontal disease. J Clin Periodontol 1982;9:290-296.

2. Egelberg J. Regeneration and repair of periodontal tissues. J Periodont Res 1987;22:233-242.

3. Aukhil I, Nishimura K, Fernyhough W. Experimental regeneration of the periodontium. Crit Rev Oral Biol Med 1990;1:101-105.

4. McCulloch CAG. Basic considerations in periodontal wound healing to achieve regeneration. Periodontol 2000 1993;1:16-25.

5. O'Neal R, Wang H-L, MacNeil RL, Somerman MJ. Cells and materials involved in guided tissue regeneration. Curr Opin Periodontol $1994 ; 141-156$.

6. Pitaru S, McCulloch CAG, Narayanan AS. Cellular origins and differentiation control mechanisms during periodontal development and wound healing. J Periodont Res 1994;29:81-94.

7. Piche JE, Carnes DL, Graves DT. Initial characterization of cells derived from human périodontia. J Dent Res 1989;68:761-767.

8. Somerman MJ, Young MF, Foster RA, Moehring JM, Imm G, Sauk JJ. Characteristics of human periodontal ligament cells in vitro. Arch Oral Biol 1990;35:241-247.

9. Somerman MJ, Archer SY, Imm GR, Foster RA. A comparative study of human periodontal ligament cells and gingival fibroblasts in vitro. $J$ Dent Res 1988;67:66-70.

10. Nohutcu RM, McCauley LK, Horton JE, Capen CC, Rosol TJ. Effects of hormones and cytokines on stimulation of adenylate cyclase and intracellular calcium concentration in human and canine periodontal-ligament fibroblasts. Arch Oral Biol 1993;38:871-879.

11. Nohutcu RM, Somerman MJ, McCauley LK. Dexamethasone enhances the effects of parathyroid hormone on human periodontal ligament cells in vitro. Calcif Tissue Int 1995;56:571-577.

12. Nojima N, Kobyashi M, Shionome M, Takahashi N, Suda T, Hasegawa K. Fibroblastic cells derived from bovine periodontal ligaments have the phenotypes of osteoblasts. J Periodont Res 1990;25: 179-185.

13. Yamaguchi M, Shimizu N, Shibata Y, Abiko Y. Effects of different magnitudes of tension-force on alkaline phosphatase activity in periodontal ligament cells. J Dent Res 1996;75:889-894.

14. Goseki M, Oida S, Takeda K, et al. Identification of bone-type alkaline phosphatase mRNA from human periodontal ligament cells. $J$ Dent Res 1995;74:319-322.

15. Arceo N, Sauk JJ, Moehring J, Foster RA, Somerman MJ. Human periodontal cells initiate mineral-like nodules in vitro. $J$ Periodontol 1991;62:499-503.

16. Lin W-L, McCulloch CAG, Cho M-I. Differentiation of periodontal ligament fibroblasts into osteoblasts during socket healing after tooth extraction in the rat. Anat Rec 1994;240:492-506.

17. Mukai M, Yoshimine Y, Akamine A, Maeda K. Bone-like nodules formed in vitro by rat periodontal ligament cells. Cell Tissue Res 1993;271:453-460.

18. Ramakrishnan PR, Lin WL, Sodek J, Cho M-I. Synthesis of noncollagenous extracellular matrix proteins during development of mineralized nodules by rat periodontal ligament cells in vitro. Calcif Tissue Int 1995;57:52-59.

19. Lang H, Schüler N, Arnhold S, Nolden R, Mertens T. Formation of differentiated tissues in vivo by periodontal cell populations cultured in vitro. J Dent Res 1995;74:1219-1225.

20. Belows CG, Heersche JNM, Aubin JE. Determination of the capacity for proliferation and differentiation of osteoprogenitor cells in the presence and absence of dexamethasone. Dev Biol 1990;140: 132-138.

21. McCulloch CAG, Tenenbaum HC. Dexamethasone induces prolif- eration and terminal differentiation of osteogenic cells in tissue culture. Anat Rec 1986;215:397-402.

22. Belows CG, Aubin JE. Determination of numbers of osteoprogenitors present in isolated fetal rat calvaria cells in vitro. Dev Biol 1989;133:8-13.

23. Kasugai S, Todescan R, Nagata T, Yao K-L, Butler WT, Sodek J. Expression of bone matrix proteins associated with mineralized tissue formation by adult rat bone marrow cells in vitro: Inductive effects of dexamethasone on the osteoblastic phenotype. J Cell Physiol 1991;147:111-120.

24. Malaval L, Modrowski D, Gupta AK, Aubin JE. Cellular expression of bone-related proteins during in vitro osteogenesis in rat bone marrow stromal cell cultures. J Cell Physiol 1994;158:555-572.

25. Rickard DJ, Sullivan TA, Shenker BJ, Leboy PS, Kazhdan I. Induction of rapid osteoblast differentiation in rat bone marrow stromal cell cultures by dexamethasone and BMP-2. Dev Biol 1994;161: 218-228.

26. Cheng S-L, Yang JW, Rifas L, Zhang SF, Avioli LV. Differentiation of. human bone marrow osteogenic stromal cells in vitro: Induction of the osteoblast phenotype by dexamethasone. Endocrinology 1994;134:277-286.

27. Lillie RD. Histopathological Technique and Practical Histochemistry. 3rd ed. New York: McGraw Hill Book Co; 1965.

28. Chomczynski P, Sacchi N. Single-step method of RNA isolation by acid guanidinium thiocyanate-phenol-chloroform extraction. Anal Biochem 1987;162:156-159.

29. Liau G, Yamada Y, deCrombrugghe B. Coordinate regulation of the levels of type III and type I collagen mRNA in most but not all mouse fibroblasts. J Biol Chem 1985;260:531-536.

30. Abou-Samra AB, Jüppner H, Force $T$, et al. Expression cloning of a common receptor for parathyroid hormone and parathyroid hormone-related peptide from rat osteoblast-like cells: A single receptor stimulates intracellular accumulation of both cAMP and inositol triphosphates and increases intracellular free calcium. Proc Natl Acad Sci (USA) 1992;89:2732-2736.

31. Terao M, Studer M, Gianni M, Garattini E. Isolation and characterization of the mouse liver/bone/kidney-type alkaline phosphatase gene. Biochem $J$ 1990;268:641-648.

32. Young MF, Kerr JM, Termine JD, et al. cDNA cloning, mRNA distribution and heterogeneity, chromosomal location, and RFLP analysis of human osteopontin (OPN). Genomics 1990;7:491-502.

33. Young MF, Ibaraki K, Kerr JM, Lyu MS, Kozak CA. Murine bone sialoprotein (BSP): cDNA cloning, mRNA expression, and genetic mapping. Mamm Genome 1994;5:108-111.

34. Findlay DM, Fisher LW, McQuillan CI, Termine JD, Young MF. Isolation of the osteonectin gene: Evidence that a variable region of the osteonectin molecule is encoded within an exon. Biochemistry 1988;27:1483-1489.

35. Celeste AJ, Rosen V, Bueker JL, Kriz R, Wang EA, Wozney JM. Isolation of the human gene for bone 'gla' protein utilizing mouse and rat cDNA clones. EMBO $J$ 1986;5:1885-1890.

36. Renkawitz R, Gerbi SA. Ribosomal DNA of the fly Sciara coprophila has a very small and homogeneous repeat unit. Mol Gen Genet 1979;173:1-13.

37. Rymaszewski Z, Abplanalp WA, Cohen RM, Chomczynski P. Estimation of cellular DNA content in cell lysates suitable for RNA isolation. Anal Biochem 1990;188:91-96.

38. Stein G, Lian JB, Owen TA. Relationship of cell growth to the regulation of tissue specific gene expression during osteoblast differentiation. FASEB $J$ 1990;4:3111-3123.

39. Aronow MA, Gerstenfeld LC, Owen TA, Tassinari MS, Stein GS, Lian JB. Factors that promote progressive development of the osteoblast phenotype in cultured fetal rat calvaria cells. J Cell Physiol 1990;143:213-221.

40. Owen TA, Aronow M, Shalhoub V, et al. Progressive development of the rat osteoblast phenotype in vitro: Reciprocal relationship in 
expression of genes associated with osteoblast proliferation and differentiation during formation of the bone extracellular matrix. $J$ Cell Physiol 1990;143:420-430.

41. Franceschi RT, Iyer BS. Relationship between collagen synthesis and expression of the osteoblast phenotype in MC3T3-E1 cells. $J$ Bone Min Res 1992;7:235-245.

42. Kasugai S, Shibata S, Suzuki S, Susami T, Ogura H. Characterization of a system of mineralized-tissue formation by rat dental pulp cells in culture. Arch Oral Biol 1993;38:769-777.

43. Lane TF, Sage EH. The biology of SPARC, a protein that modulates cell-matrix interactions. FASEB $J$ 1994;8:163-173.

44. Ibaraki K, Termine JD, Whitson W, Young M. Bone matrix mRNA expression in differentiating fetal bovine osteoblasts. $J$ Bone Min Res 1992;7:743-753.

45. Takano-Yamamoto T, Takemura T, Kitamura Y, Nomura S. Site-specific expression of mRNAs for osteonectin, osteocalcin, and osteopontin revealed by in situ hybridization in rat periodontal ligament during physiological tooth movement. $J$ Histochem Cytochem 1994;42:885-896.

46. Nohutcu RM, McCauley LK, Shigeyama Y, Somerman MJ. Expression of mineral-associated proteins by periodontal ligament cells: in vitro vs. ex vivo. J Periodont Res 1996;31:369-372.

47. Boyko GA, Melcher AH, Brunette DM. Formation of new peri- odontal ligament by periodontal ligament cells implanted in vivo after culture in vitro. $J$ Periodont Res 1981;16:73-88.

48. Melcher AH, Cheong T, Cox J, Nemeth E, Shig A. Synthesis of cementum-like tissue in vitro by cells cultured from bone: A light and electron microscope study. J Periodont Res 1986;21:592-612.

49. Liu F, Malaval L, Gupta AK, Aubin JE. Simultaneous detection of multiple bone-related mRNAs and protein expression during osteoblast differentiation: Polymerase chain reaction and immunocytochemical studies at the single cell level. Dev Biol 1994;166:220234.

50. Tenenbaum HC, Heersche JNM. Dexamethasone stimulates osteogenesis in chick periosteum in vitro. Endocrinology 1985;117:12111217.

51. Chung $\mathrm{CH}$, Golub EE, Forbes E, Tokuoka T, Shapiro MI. Mechanism of action of $\beta$-glycerophosphate on bone cell mineralization. Calcif Tissue Int 1992;51:305-311.

52. Belows CG, Aubin JE, Heersche JNM. Initiation and progression of mineralization of bone nodules formed in vitro: The role of alkaline phosphatase and organic phosphate. Bone Miner 1991;14:27-40.

Send reprint requests to: Dr. Laurie K. McCauley, Department of Periodontics/Prevention/Geriatrics, School of Dentistry, University of Michigan, 1011 N. University Ave., Room 3397, Ann Arbor, MI 48109-1078. Accepted for publication September 3, 1996. 